\title{
Research on the Transformation of Bonded Area to Pilot Free Trade Zone in China's Inland
}

\author{
Chao Shi \\ Faculty of International Economics and Trade \\ Changchun University of Finance and Economics \\ Changchun, China
}

\author{
Yang Dang \\ Faculty of Economics \\ Changchun University of Finance and Economics \\ Changchun, China
}

\author{
Lijuan Liu \\ Jilin University of Finance and Economics \\ Jilin, China
}

\begin{abstract}
On the basis of explaining the connotation of contemporary free trade area and combining with the development strategy of China's bonded area under "One Belt, One Road", this paper has summarized the objective problem of unbalanced development of China's inland bonded area and coastal bonded area. Then, taking Shanghai Free Trade Zone as an example, this paper has analyzed the transformation conditions, system innovation and function innovation forthe conduction of China's comprehensive bonded area. There are some corresponding suggestions on the construction and development of bonded area in the inland after getting the conclusion that the development strategy of Free Trade Zone in Shanghai can be used in other areas.
\end{abstract}

Keywords-China; bonded area; pilot free trade zone; transition

\section{INTRODUCTION}

\section{A. The Connotation of Free Trade Zone}

At present, the international definition of free trade zone has two different perspectives. The first one is free trade area, called "FTA"; this is from Free Trade Area or Free Trade Agreement. Free trade area refers to an international economic integration organization by two or more countries a treaty or treaty for canceling the tariffs or other agreements that have same function with tariffs. But the one that we mention in this paper is not like this. The second one is free trade zone, known as "FTZ", which is set up for the promotion of foreign trade. According to the 1973 Kyoto Convention, it is defined as a part of the territory of a country, where the import duty and other taxes are considered to be outside the customs and are exempt from the custom control system. This concept is consistent with the definition of free trade zones in this paper.

At present, the naming of free trade zone is different

This paper is theresult of the 13th Five-Year Plan social science research and planning project by the Ministry of Education in Jilin Province under the background of "One Belt, One Road" for the optimization of bonded zone.(No: JESC Text [2016] No. 556). according to their functions. Such as foreign trade zone in the United States; free port in Italy and Hong Kong; bonded warehouse area in Japan and the Netherlands; and free customs zone, free zones, export processing zones and science industrial parks in other countries. Therefore, there are different standards for the classification of free trade zones. For instance, according to its policy specificity, it will be divided into exclusive free trade zone and non-exclusive free trade zone; according to the free trade area ownership and management rights, it will be divided into government free trade zone and company free trade zone. According to its function, it will be divided into single functional free trade zone, logistics center type free trade zone and integrated free trade zone.

The common one that we can see is functional classification. According to the international free trade zone construction condition, there are the specific types: free port, reentry distribution, trade union, export processing, bonded warehousing, commercial retail and border trade and industry. Their specific functional positioning, regional characteristics and the type of typical free trade area are described in Table 1.1. According to Table 1.1, it can be seen that the functional orientation of the free trade zone is determined by its location conditions and trade flows. Different organization form and management model are applied for better function playing. Therefore, the inherent law of the function of free trade zone is special political, economic and geographical environment determines its functional orientation, which determines the target model of free trade zone.

\section{B. The Characteristics of Free Trade Zone and the Conditions for Its Construction}

The common feature of free trade zones in the world is sovereignty of a nation or region. Politically, all free trade zones are free economic zones within the border while outside the customs. Goods there are not subject to customs supervision. Functional space of FTZ can be expanded. 
For successful construction of the free trade zone, the following conditions should be taken into consideration according to basic situation of various types of free trade zones in the world.

- The level of infrastructure construction is higher than the average level of that region. Free trade zones should provide enterprises and companies infrastructure and services that are higher than the average level of that country.

- The location should be in the logistics convenient area to enjoy location advantages. At present, the development trend of the world's major free trade zones is dominated by the logistics area, thus convenient and efficient logistics services can improve the overall efficiency for their participating in the global supply efficiency chain.

- Preferential construction policy. Free trade zone customs supervision should be relatively looser, faster and more efficient than that outside. There should be more and more ways for attracting foreign investment and labors. Business regulations should be looser somewhat.

- Superior economic conditions with export trade advantages.

\section{GENERAL SituAtion AND PROBLEMS BondED AREA CONSTRUCTION IN CHINA}

\section{A. The Construction Profile}

Since the reform and opening up, China's economy has improved year by year, entering into the new normal. The construction of free trade zone has become a new engine and a supporting point for regional economic growth under the "One Belt, One Road" strategy. At the same time, the construction of free trade zone is also a major opportunity for China's economic development. China has set up special economic zone (SEZ), also known as bonded zone in the southeastern coastal areas since the 1980s. Its purpose is to achieve the expansion of trade scale, promote trade development, and to attract foreign investment and increase employment, where policies like tariff reduction, free trade and funds, investment concessions and other special customs systems and policies are implemented. In 1994, the State Council formally approved the establishment of China's first bonded area named Shanghai Waigaoqiao Free Trade Zone began. And in 2013, Shanghai pilot Free Trade Zone was established. The development of China's bonded zones is very fast. As of the first half of 2013, according to the customs statistics, there are 110 special economic zones that are with bonded function in China, including 12 bonded zones, 50 export processing zones, 5 bonded logistics centers, 14 bonded port areas, 27 integrated bonded areas, and 2 cross-border industrial zones. From the functional and formal point of view, bonded port area and comprehensive bonded area and is similar to free trade zone. While from the practical point of view, comprehensive bonded zoneis similar to free trade zone. However, the development of
China's comprehensive bonded zones is imbalanced, mainly reflected in the following aspects.

\section{B. The Problems in the Development of Inland Comprehensive Bonded Zones in China}

- Imbalanced strategic layout. Emphasis on East China, South China and North China with 18 comprehensive bonded areas in total, instead of northeast and northwest and other inland areas with 10 in total.

- Imbalanced import and export trade. The distribution of 25 comprehensive bonded areas is different, and the eastern coastal bonded area is superior to other regions in the total value of import and export, the number of bonded areas and functional orientation. In Jiangsu Province, there are 6 comprehensive bonded areas, the largest number in China, with a total import and export value of 92.772 billion US dollars from January to November in 2014, accounting for all the comprehensive bonded area of the total import and export accounted $47.3 \%$ of the total number in China. There are 3 comprehensive bonded areas in the northeastern region, of which Suifenhe Comprehensive Bonded Area in Heilongjiang Province is the smallest, but the total import and export volume from January to November 2014 ranked first in these three in Northeast China with a number of 14.2 billion US dollars ranked 14th in the whole country. The total import and export value of Shenyang Comprehensive Bonded Area from January to November is 155 million, ranking 19. At the same time, total value of import and export in Changchun Xinglong Comprehensive Bonded Area was US \$ 6.94 million, ranking 23.Total value of import and export of the three bonded areas accounts for only $0.56 \%$ of the total number in China.

- Mainstream business development degree and model is not balanced. Although functional positioning of the bonded area is consistent theoretically, the development degree and model of each are different. The top ten comprehensive bonded areas are basically based on the electronics industry, information industry and production services, and they have entered into the global industrial supply chain by making use of regional advantages to create an international logistics hub node. In northeast, northwest and other regions, comprehensive bonded area are still relying on bonded logistics, processing. If there is no breakthrough development, it will be difficult for them to integrate into the global industrial supply chain.

According to the analysis, we can see that China's comprehensive bonded area is the special bonded area that has transition basis pf the customs administrative area from the functional positioning, regulatory system and trade performance. However, from the strategic layout, trade scale and development level, the current development of China's comprehensive bonded area is uneven. Therefore, the construction of China's comprehensive bonded area cannot be generalized, it should be based on local conditions, based on 
which, and to explore the potential advantages of regional comprehensive bonded area. Then, build a functional model with development potential, and enter into the global supply chain and develop modern service industry. In 2014, the Shanghai Pilot Free Trade Zone was set up, and people began to study its "Repeatable and Propagable" system with characteristics, some of which could provide reference for the construction of inland comprehensive bonded zone.

\section{The ENLightenMent Provided By ChInA (ShANGHAI) PILOT FreE TRADE ZONE ON THE CONSTRUCTION OF INLAND INTEGRATED BONDED AREA}

On September 29, 2013, China (Shanghai) Pilot Free Trade Zone was formally established. Since then, Shanghai Free Trade Zone has been considered as "China Economic Upgrade Edition" and "China's reform vane". And it is the new engine for Chinese foreign trade growth under grand situation. As early as 2003, Professor Cheng Siwei has analyzed the importance and feasibility for the establishment of free trade zone in Shanghai in the "China Bonded Zone Reform and Development". He thought that it is the key for breaking the bottleneck of Reform and Opening up. Its background, functional orientation, transition conditions and policy characteristics would have important reference value for other bonded area construction, transition and upgrading in the future.

\section{A. The Objective Conditions for the Establishment of Free Trade Zone in Shanghai}

1) Geographical factors are the objective basis for establishment: Shanghai's geographical factors are mainly manifested in three aspects. First of all, convenient traffic condition is an important foundation for Shanghai. From the geographical aspect, Shanghai can be connected to the middle, western, and eastern region in inland, and can be linked to the "Yangtze River Delta" and "Pearl River Delta". It has a good port conditions, making Shanghai a center for international businesses, talents, funds, commodity economy and other aspects. These are important conditions for transnational corporate distribution of global production and network marketing. Second, the location advantage makes Shanghai available to accept the economic transmission of developed countries. Business cooperation with Japan, South Korea, Southeast Asia, Indonesia, and even the United States, Australia and other countries has played a good role in promoting Shanghai's economy. In this way, internationalized Pacific economic circle has been built which is good to Chinese economic development. Finally, Shanghai can attract a large number of advanced technology and foreign capital because of its good conditions. A large number of talented human resources (and natural resources), good infrastructure, and regional service industry here are easy to form the effect of industrial clusters, and to create a good cross-border production, services, financing, research and development system.
2) The strong hinterland economy is a necessary condition for its establishment: Hinterland economy is an important condition for Shanghai free trade zone function to play its function and be an international shipping center. From the domestic hinterland, Shanghai mainly relies on the "Yangtze River Delta". There are 16 cities around Yangtze River Delta, with an urban population of more than 100 million, with the GDP of 9 trillion yuan in 2012, about 1.45 trillion US dollars. Creating $22.1 \%$ of total GDP, $24.5 \%$ of the revenue, $28.5 \%$ of the total import and export with $2.2 \%$ of the land area and $10.4 \%$ of the population. It is one of China's economic, scientific and technological, cultural developed area, which provides a strong hinterland economic support for Shanghai Free Trade Zone. Hinterland economic development and Shanghai Pudong New District have influence on each other's development. Hinterland economy promote the development and opening up the Shanghai Pudong New District, while it plays an leading role for hinterland economic development.

3) Completed infrastructure and industrial base: Since the 1990s, Shanghai Pudong New District as the core area has strengthened the infrastructure construction, into which more than 2000 billion yuan has been invested. Making use of hundreds of major projects, functional hubs like Yangshan Port, Pudong International Airport and Waigaoqiao port have been built. What's more, transportation system connecting sea, land and air has been built. At the same time, Shanghai has also been a well-known comprehensive industrial city, an important business, manufacturing and $\mathrm{R} \& \mathrm{D}$ center base, while exploring the development of high standard, new model of high-tech industries and modern service industry. In the past 20 years, the industrial structure of Pudong District has been optimized continuously. In 1990, the proportion of the three industries in Pudong was 3.7: 76.2: 20.1. The proportion of the tertiary industry in 2007 exceeded that of the secondary industry for the first time, and initially formed tertiary, second and first industry of modern city pattern. As of 2008, ratio of these three industries in Putong0.2: 45.4: 54.4. The proportion of the secondary industry decreased by 30.8 percentage points compared with that in 1990 . The proportion of the tertiary industry increased by 34.3 percentage points compared with that in 1990. In 2016, the proportion of these three industries was 0.4: 29.1: 70.5 .

Production factors will have influence on the development of regional economy. There are many well-known universities and research institutes in Shanghai, the number of which ranks second following Beijing in China and ranks in the port city. According to the Shanghai Municipal Statistics of the People's Republic of China in 2013, the number of employed persons in the tertiary industry in Shanghai reached 6.449 million in 2013 , while the added value of the tertiary industry accounted for $62.2 \%$ of Shanghai's GDP, increased by 1.8 percentage points over the previous year.

4) Adequate production factors show potential advantages: These data demonstrate the promotion function 
of high-quality labor force to related industries. According to statistics, in 2013, research and experimental development expenditure was 73.7 billion yuan in Shanghai, equivalent to $3.4 \%$ of Shanghai's GDP. The number of patent applications was 86,450 , with an increase of $4.6 \%$ over the previous year. The number of city's national innovation Enterprises reached 15, state-level innovative pilot enterprises 19, municipal innovation-oriented enterprises 500, science and technology giant and the cultivation enterprises1014, high-tech enterprises 5140, advanced technology services 298. During the year, the city identified and reviewed high-tech enterprises had a number of 1446; 709 projects of high-tech achievements were identified, of which $86.3 \%$ were in key fields, such as electronic information, biomedicine and new materials. By the end of 2013, a total number of 9254 projects of high-tech achievements were identified. Throughout the year, 26.63 contracts of all kinds of technical transactions were registered. The value of contracts was RMB 6.2287 billion, increased by $5.5 \%$. In addition, Shanghai Pudong District also has a good financial industry advantages with mature modern financial market system. Transaction scale has been expanded, the number of financial institutions and value of the financial industry has also been increased, which can help to lay a good foundation to build Shanghai an international financial center.

In addition to the initiative advantages, its location and hinterland economic development, completed infrastructure, good industrial structure, and rich financial capital and talents have laid a solid foundation for the establishment of the FTA, while other cities in China don't have such conditions.

\section{B. Inland Comprehensive Bonded Area Can Learn from Shanghai Pilot Free Trade Zone System}

1) Some regulatory functions and trade patterns can be copied: Some comprehensive bonded areas can be transferred into free trade zone. The new customs supervision mode of Shanghai Pilot Free Trade Zone that "first-tier release, second-tier management" can be copied in the following points:

a) To develop headquarters economy: "Siphon Effect" of the reform of the Shanghai Free Trade Zone has theoretically been conducive to the development of the Shanghai headquarters economy. Although the economic development of Shanghai headquarters is facing some difficulties, if higher functional headquarters can be gathered, it will be helpful for headquarters economic development in other regions.

b) To create a "platform economy": There is no clear definition of "Platform Economy". Practically, it is generally refers to a city or region that has the function of trade, services, finance, logistics, information exchange and distribution by using the network platform to make both the seller and buyer successfully do their trade. This economic phenomenon is what we call Platform Economy, and the international economic center like New York, Tokyo, London and Hong Kong have the above functions and characteristics. The construction of "Platform Economy" is an important foundation for the development of modern service industry, international logistics supply chain, headquarters economy and international industrial chain. Compared with other international cities, Shanghai's Platform Economy is less developed, but its model and experience can be learned by other free trade zones.

c) Financial leasing: One of the most promising industry of Shanghai pilot FTZ is financial leasing, which was born in San Francisco in the 1960s. The best connection for industry and finance is periphery sector that integrated with trade, finance, services. The financial leasing is one of the three major financial services field, according to "China (Shanghai) Pilot Free Trade Zone", which does not have the minimum capital limit for the finance leasing companies, clarifies the scope of the financial leasing export tax rebate, allows the financial leasing company to set up factoring business. To explore the establishment of integrated service platform of financial lease, the global model manufacturers of leasing company, the integrated development of financial leasing industry and e-commerce, the establishment of a unified market transactions, the professional financial leasing registration system and settlement system. These will provide valuable experience for other FTZs.

2) Repeatable innovation management model: The management models of Shanghai Free Trade Zone that can be copied to other comprehensive bonded areas are as following:

a) "Negative List" management model and the corresponding foreign access registration system: International "Negative List" management model has two characteristics: First, there is a high degree of openness of the service industry. Second, the industry restriction of openness is small. In addition, different commitment models can be applied in different industries. For the comprehensive bonded areas in some underdeveloped areas, some industries apply the model of negative list, while the others use positive list model. Those that don't adopt negative list should apply foreign access registration system to simplify the registration procedure. The registered capital of the enterprise is changed from "overdue system" to subscription system. The reason is nothing more than to simplify the procedure and improve the efficiency.

b) Expand the opening field and way of service industry: On the one hand, the financial, shipping, business and other service system should be improved. At the same time, attention should be paid to the construction and openness of professional services, cultural services and social services and other areas. According to the existing policy of Free Trade Zone, the access restrictions such as the qualification requirements of the service industry investors in the region, the restriction on the scope of the shares and the restrictions on the scope of business are suspended or canceled, except for the banking institutions and information and communication services. Market access is conducive to maintaining the interests of all types of investors.

c) Build a global trade network and industry valueadded chain strategy: As of Dec. 2013, there were 3386newly 
established domestic enterprises in Shanghai Pilot Free Trade Zone, with a total registered capital of 68.467 billion yuan. There were 225 newly established foreign-invested enterprises with a registered capital of US \$ 978 million; 48 financial institutions with licenses (9 Chinese, 12 foreign), more than 200 financial information service and capital management agencies. In addition to the enterprises mentioned here, there are 403 foreign companies, 265 foreign-invested companies and 351 foreign-invested $R \& D$ centers, including the global headquarters of ABB's Robotics Division, the global headquarters of Bayer's materials and technology division, The New GM North American market international operations headquarters and other national wellknown enterprises. Business practice, the development model and transformation experience and reflection by these companies will be learned by companies in other comprehensive bonded areas.

Through the analysis, we can see that a comprehensive bonded area in inland economic underdeveloped area should identify and use their existing advantages, use potential advantage and geographical features, develop hinterland economy, improve infrastructure and adjust the industrial structure, integrate regional factors of production. In this way, it is possible to play its function and be better developed.

\section{ADVICE FORTHE TRANSITION AND DEVELOPMENT OF CHINA'S INLAND BONDED AREA}

\section{A. Increasing the Total Economic Value Is an Important Basis for the Development of Bonded Zone}

Hinterland economy is the key for the transition of bonded zone development. Therefore, bonded areas in inland provinces should take use of regional advantages. Their economic development can rely on logistics industry or local products supplemented by tourism, trade, technical cooperation and other services to enhance the regional economic aggregate. The current situation of China's inland bonded area is as following. The bonded areas in North China have great potential, because they are near the capital city. The central area bonded area, such as Xinzheng Comprehensive Bonded Zone can benefit from Beijing, Hong Kong, Macao, Fuzhou, Xiamen and other regions. With the G4 (Beijing, Hong Kong and Macao highway), it is suitable for building a logistics node-type city; Southwest Bonded Zones are population-intensive, though the economy is less developed, with the policy assistance and abundant resources, they can also develop well.

\section{B. Industrial Restructuring and Logistics Access Is the Key to the Development of Bonded Zone}

The positioning of inland comprehensive bonded zones is similar. It is difficult to see the local advantages and the linkage relationship among them. It is important to know that the construction of the bonded zones should be beneficial to the provinces. And it is an important strategy for the opening up of the country. Therefore, the industrial structure should be adjusted according to the provinces' economy to improve overall economic value and cooperate with other neighbor provinces. What's more, we must open the logistics of access, and smooth flow of goods can help enhance the economic efficiency of the bonded zones.

\section{Supervision Model Should Be Innovated in the Bonded Zone}

So far, most of our bonded zones are managed by government agencies, instead of private companies, which is quite different with the well-known international bonded zones. In addition, we don't have the authority, unified, clear government department to regulate the bonded zones. These factors lead to poor market orientation and low efficiency between departments and bonded zones. From a micro perspective, different bonded zones, even if the functional positioning is the same, the specific types of business and business volume are also different. So the construction, supervision, and operation of the bonded zones should be carried out according to their situation.

\section{Deepening the Cooperation between Bonded Zones in Adjacent Provinces}

American economists have come to the conclusion that there will be no trade barriers among China's provinces. The current situation is that though it is the representative of "openness", there is no much connection among these bonded areas. Therefore, cooperation among these bonded zones should be strengthened. The conduction of economy will be reflected in different stairs, which is also the reason that we establish bonded zones and special economic zones in coastal areas. If the economic conduction cannot be realized, it will be no meaning to build bonded zones.

\section{E. Establishing Competitive Mechanism to Cultivate the Core Competitiveness of the Bonded Zone}

Through the analysis, we can know that the bonded zone can only realize its goal by systematic, scientific and sustainable development planning and policy guidance. Therefore, competitive mechanism should be established among bonded zones. Designated department should be responsible to the evaluation of these bonded zones. Those who enjoy better development should be awarded, while those cannot develop well should be guided. If they cannot bring benefit and even bring negative result to the government finance, they are supposed to be repealed. This kind of strategy is also the key for innovation. It will be helpful for them to play their advantages, instead of copying others' model. In this way, they will be more competitive.

\section{CONCLUSION}

In order to practice strategy of reform and opening-up, China built a lot of bonded zone. As one of the types, comprehensive bonded zones, have the best conditions to be converted into a free trade zone. One of a new round of reform and opening up, the goal of China is to build the free trade zone to carry out the offshore service trade and the global supply chain .The conditions for the building of the area, the construction background and development path of China's comprehensive free trade zone in coastal provinces and inland provinces are different. Coastal bonded zone has the function 
of diversification, inland bonded park features traditional and single. It makes the inland bonded zone cannot directly use the development model of coastal bonded zone. Therefore, the construction of the comprehensive bonded zone in inland provinces must choose a suitable development path.

The article first discusses the contemporary free trade area theory connotation, main types and construction conditions, combining with current situation of the development of China's inland provinces comprehensive bond zone. It is pointed out that the development between the coastal province comprehensive bond zone and inland province comprehensive bond zone are unbalanced. After that, do research of the construction environment of the comprehensive bond zone in China's inland provinces. Make the contrast analysis to clarify the strengths, weaknesses, opportunities and threats of comprehensive bond zone. To probe into comprehensive bond zone construction objective problems and puts forward Suggestions on the future construction. Finally, conclusion the development experience of international free trade zone located in the inland and the China (Shanghai) Pilot Free Trade Zone Can be used by inland comprehensive bonded zone. Give advice to the Chinese inland comprehensive bond zone on the existing problems in the common development.

\section{REFERENCES}

[1] Li Renqing. Research on the Model Transition of Shanghai Comprehensive Bonded Area to Free Trade Zone $[\mathrm{J}]$. Logistics Technology, 2014,33 (1).

[2] Shanghai University of Finance and Economics Free Trade Zone Research Institute, Shanghai Development Research Institute .2014 China (Shanghai) Pilot Free Trade Zone Development Research Report [Shanghai]: Shanghai University of Finance and Economics Press, 2013.

[3] Li Boxi, Zhou Feiyue, Sun Bing. Construction of China Free Trade Zone [M]. Beijing: Mechanical Industry Press, 2013.

[4] Tianjin Free Trade Zone Strategic Research Group, Li Wenzeng. Research on the Construction of Tianjin Pilot Free Trade Zone with Dongjiang Bonded Port Area and Tianjin Port Free Trade Zone [J]. Economic Outlook the Bohaisea, 2014,3.

[5] Zhu Jing. Research on the Transition of Chinese Bonded Area to Free Trade Zone [J]. Economic Research Guide, 2013,32.

[6] Chen Keyan. Research on the Transition of Chinese Bonded Area to Free Trade Zone [D]. Tianjin: Tianjin University; Business Administration, 2012.

[7] Cheng Siwei. From Bonded Area to Free Trade Zone - Reform and Development of Chinese Bonded Area [M]. Beijing: Economic Science Press, 2003.

[8] Wu Junkui. Research on the Transition Strategy of Chinese Bonded Area to Free Trade Zone [J]. Modern Economic Information, 2013,12.

[9] Huang Tian. Shanghai Free Trade Zone's function and Its Prospect [J]. Western Forum, 2014, 24 (04).

[10] Zhao Tao, Cheng wei, Li Junjing, Shenyang offshore bonded competitive analysis and function, ICAMS2010: IEEE International Conferrence on Advanced Management Science, VZ, 2010: 224-227.

[11] Mary Jane Bolle, Brock R Williams.U.S. Foreign-Trade Zones: Background and Issues for Congress [R]. 2012.

[12] Chengrong PAN, Achievements and Problems of Reform of Investment Management System for Shanghai Pilot Free Trade Zone [J]. Asian Agricultural Research, 2014, 6 (11). 